\title{
A Study on the Relationship between Employee Engagement and Organizational Citizenship with Reference to Employees Working in Travel Organizations
}

Ginu George* and Binoy Joseph ${ }^{\dagger}$

\begin{abstract}
All sectors across the globe have started looking at employee engagement as an opportunity because engaged employees always tend to perform better than not engaged or disengaged employees. Organization with engaged employees are always a strength to the organization as it has lot of positive outcomes. This article elucidates the relationship that exists between employee engagement and organizational citizenship behaviorwith reference to employees working in travel organizations. The study focuses on employees working in national and international travel organizations which arelocated in Bangalore. Data was collected with the help of an adapted questionnaire. The findings of the study will help the employers to understand the importance of these two factors and their present engagement and OCB level of the employees working in these organizations and take measures accordingly.
\end{abstract}

Keywords: Employee engagement; OCB; travel organizations

\footnotetext{
"PhD Scholar, Christ University, Bangalore, India; ginu.george@christuniversity.in

tProfessor, Rajagiri School of Management, Cochin, India; binoyjoseph@rajagiri.edu
} 


\section{Introduction}

Travel and tourism industry plays a major role across all countries, and this is more evident with respect to India. It is considered as the largest service industry which contributes a considerable portion to the nation's GDP as well as to the world's GDP. According to the statistics provided by World Travel and Tourism council (WTTC) in 2015, the total GDP contribution by travel and tourism industry in 2014 was 6.7 per cent of India's GDP; with respect to employment in 2014 it was 8.7 per cent of total employment. This is one of the fastest growing sectors and India has a huge potential to become one of the most chosen destinations among the international tourists as it is known for its diverse culture and heritage. Travel and tourism industry consist of different sub sectors such hotels, travel trades, airlines, cruises, railways and so on. This study focuses on one of the sub sector of tourism industry i.e. travel trades which are otherwise known as travel organisations, tour operators or travel agencies. These are intermediaries between the suppliers (hotels, railways, airlines) and buyers (customers or travelers) and help the travelers in planning and executing their tours.

Thus satisfaction of travelers' lies based on efficiency of employees in designing a good travel package. An employee can be efficient and committed only when they are engaged and it also has a direct impact on customer satisfaction. But sometimes organisations neglect the importance of having good employees with positive attitude; rather they look at them as a continuous liability. It is important for the organisations to realize that employees are no more a liability and rather a valuable asset and consider them as an integral part of the organization. The organization need to have happy and engaged employees as it has lot of positive benefits such as profits, easy survival in the industry, getting innovative ideas from the employees, gaining skill sets for successful functioning of a business, customer loyalty and many more. 


\section{Review of Literature}

\section{Employee engagement}

Khan (1990) developed the concept "Personal Engagement", which explained it as "harnessing of organization members' selves to their work roles"; in engagement, people employ and express themselves physically, cognitively and emotionally during role performances. Personal disengagement means "uncoupling of selves from work roles"; in disengagement "people withdraw \& defend themselves physically, cognitively and emotionally during role performances". According to Khan, (1990) there are three psychological conditions whose presence will lead to engagement and absence will lead to disengagement. They are psychological meaningfulness, psychological safety and psychological availability. Though, Khan was the one who developed and explained the concept "engagement", the term "employee engagement" was first coined and applied in businesses by a consulting firm Gallup in 1999. Employee engagement was defined by Buckingham and Coffman (1999) as, "a fully engaged employee as one who could answer yes to all 12 questions on Gallup's work place questionnaire". Even though Khan developed and defined the concept, operationalization of the construct was not put forth. Maslach and Leiter (1997) had a different approach towards engagement. The authors defined as "the antithesis of burnout as engagement", where engagement is measured with the opposite constructs of burnout. Hence the constructs of engagement consist of energy in place of exhaustion, involvement instead of cynicism and efficacy instead of inefficacy. The opposite scores received through measuring $\mathrm{MBI}$ are used in measuring engagement (Maslach\& Leiter, 1997). However, later it was understood that burnout is a different construct from engagement, hence the realization of measuring engagement as a separate construct led to the development of three constructs, namely vigor and dedication (Schaufeli\& Bakker, 2001) and absorption (Schaufeli et al., 2001). Thus engagement is not an activity which remains only for a particular moment rather it is a state which remains constant for a longer period (Schaufeli et al., 2001). Thereby employee engagement was redefined as "positive, fulfilling, work-related state of mind that is characterized by vigor, dedication, and 
absorption" (Schaufeli et al., 2001). There are many other authors who have contributed to this concept and defined it with different dimensions. May, Gilson and Harter (2004) defined the dimensions of employee engagement based on Khan's work which includes meaningfulness, safety and availability. Employee engagement is more based on a give-and-take relationship, which is also referred to as "social exchange theory", thus employee engagement is measured based on the emotional, cognitive and physical resources one is willing to devote based on the resources received from the organization (Saks, 2006). There are different views about employee engagement, some mentioning it as "state engagement", "trait engagement" or "behavior engagement". This was well brought out by Macey and Schneider (2008), where it was clearly mentioned how employee engagement is defined differently based on the three facets and as pointed out, that employee engagement is more like a state, and variables comprising of trait engagement are more like independent variables or antecedents of employee engagement, and the behavior engagement such as OCB, role expansion or being adaptive are the outcomes of state engagement.

One of the recent measures developed for employee engagement by Soane et al., (2012) consisted of three dimensions such as intellectual, social and affective. The authors developed the ISA employee engagement measure supporting and agreeing with the majority of authors' view that engagement is a state and behavior enacted by the employees are more of the consequences of employee engagement. The authors defined intellectual engagement as "the extent to which one is intellectually absorbed in work", social engagement as, "the extent to which one is socially connected with the working environment and shares common values with colleagues", and finally affective engagement is defined as "the extent to which one experiences a state of positive affect relating to ones work role".

\section{Organizational citizenship behavior}

OCB is defined as "individual behavior that is discretionary, not directly or explicitly recognized by the formal reward system, and that in the aggregate promotes the effective functioning of the organization (Organ, 1988. P.4). And based on this study five 
dimensions of OCBs consisting of altruism, conscientiousness, courtesy, sportsmanship and civic virtue was constructed, however the OCB measuring scale was developed by Podsakoff, Mackenzie, Moorman \& Fetter (1990) which consisted of 20 items. There are also many studies based OCB by different authors defining OCB as an extra role behavior or as an in role behavior. However the most widely used definition of OCB was by Organ and scale used for measuring OCB was by Podsakoff, Mackenzie, Moorman \& Fetter (1990) as the constructs of the other scales seems to overlap with these constructs.

\section{Relationship between Employee engagement and OCB}

There are studies which has carried on to determine the relationship of employee engagement and OCB and proved to have a positive relationship. A study based on Thai organizations by Rurkkhum (2010) found that there exist a positive relationship between employee engagement and OCB. The author measured OCB based on 5 dimensions such as altruism, civic virtue, sportsmanship, courtesy and conscientiousness developed by Podsakoff et al (1990). Except courtesy, which indicated a weak relationship all the other variables such as altruism, civic virtue, sportsmanship and conscientiousness indicated a positive relationship with employee engagement. A similar study based on employees working in various sectors situated in Malaysia supported the finding wherein except courtesy all the other four constructs had positive relationship with employee engagement (Islam et al., 2012). Few other studies which supported the positive relationship are (Saks, 2006; Thayer, 2008; Thomas, 2011; Barman, 2012; Finkelstein, 2013). From the reviews the following hypothesis was developed and was tested.

$\mathrm{H}_{1}$ : There is a significant and positive influence of employee engagement on organizational citizenship behavior

\section{Need for the Study}

Travel and Tourism industry is a fragmented industry which has many small and medium sized companies. This is same in the case of travel organizations; also there are other downsides in this sector such as low wages, long working hours during seasons and less 
career opportunities. Similarly the nature of travel organizations is completely labour intensive were the main objective is customer service and meeting their demands without any hassle and on time. The employees working in these organizations are expected to always give a positive impression about themselves and about the company as they are always directly in contact with customers. Another difficult task this industry faces is maintaining customer loyalty. These aspects could be achieved only through employees as they are the connecting point between the organization and the customers (tourist). An employee who is not engaged or disengaged will not able to help in achieving any of these, but if an organization is having engaged employees then the results the organizations gain are favorable. One such favorable outcome is OCB, were the employees are always prepared to do something extra and go one step ahead than the given work. Thus this study explores the relationship between employee engagement and OCB on employees working in travel organizations. The findings will help the travel organizations to understand whether there is any positive relationship that exist and strategize the human resource management accordingly.

\section{Research Methodology}

Population, sample size and sampling technique: The population of the study consisted of employees working in travel organization which is set up in Bangalore. Travel organizations covered in this study included both national and international travel organizations. Travel organizations which were selected for the study had a certain predetermined criteria's such as it should be an organization consisting of more than 10 employees and having been established for more than a year. The sample size of the study consisted of 433 employees working in these organizations having more than one year experience because as Byrne (2005) has mentioned that individuals in their first year of employment in any organization tend to exhibit higher organizational citizenship behavior and are more likely to be engaged in order to establish themselves in the organization and make their job secure. Thus the sampling technique adopted for the study was purposive and convenience sampling. 
Sources, method and tools of data collection: The research used both primary and secondary sources. Primary data was collected based on a survey method and secondary data was gathered from articles, thesis, books, and websites. The tool used to collect data was questionnaire. It was an adapted and structured questionnaire after seeking prior permission from the authors. Employee engagement was measured by ISA engagement scale which was developed by Soane et al, (2012) and psychological climate was developed by Brown and Leigh (1996)

Tools for analysis: Cronbach alpha was done to check the reliability of the scale and the values were found to be more than required. Employee engagement had an alpha value of .892 and psychological climate with .860. Mean score was calculated to understand the engagement and OCB level of the employees. Correlation and regression was used to test the hypothesis.

\section{Results and Discussion}

(a) Descriptive statistics: The study also computed the mean score to find out the level at which the employees are engaged and exhibiting OCB.

Table 1 shows mean scores which are computed for employee engagement dimensions

\begin{tabular}{|l|c|}
\hline \multicolumn{1}{|c|}{ Employee engagement dimensions } & Mean \\
\hline Intellectual engagement & 3.99 \\
\hline Social engagement & 3.60 \\
\hline Affective engagement & 3.82 \\
\hline Overall mean & $\mathbf{3 . 8 1}$ \\
\hline
\end{tabular}

Employee engagement was measured on a scale of 5 and from the above table it can been seen that mean scores of employee engagement and its sub-dimensions are above 3.5 and closer to 4.0 which indicates that employees in travel organizations are to an extent intellectually, socially and affectively engaged 
Table 2 shows mean scores computed for Organizational citizenship behavior dimensions

\begin{tabular}{|l|l|}
\hline Organizational citizenship behavior dimensions & Mean \\
\hline Altruism & 3.74 \\
\hline Conscientiousness & 3.77 \\
\hline Sportsmanship & 3.50 \\
\hline Courtesy & 3.73 \\
\hline Civic virtue & 3.98 \\
\hline Overall mean & $\mathbf{3 . 7 3}$ \\
\hline
\end{tabular}

In case of $\mathrm{OCB}$, the sub dimensions such as altruism, conscientiousness, courtesy and civic virtue had a mean score between 3.5- 4.0 which indicates that employees in travel organizations are willing to exhibit citizenship behavior.

(b) Hypothesis testing: The hypothesis of the study was tested with help of correlation and regression. Correlation was used in order to understand the predictive relationship between employee engagement (EE) and organizational citizenship behavior (OCB)

$\mathrm{H}_{1}$ : There is a significant and positive influence of employee engagement on organizational citizenship behavior

Table 2.1 Correlations

\begin{tabular}{|l|l|r|r|}
\hline \multicolumn{2}{|c|}{} & EE & OCB \\
\hline \multirow{3}{*}{ EE } & Pearson Correlation & 1 & $.687^{* *}$ \\
\cline { 2 - 4 } & Sig. (2-tailed) & & .000 \\
\cline { 2 - 4 } & $\mathrm{N}$ & $.687^{* *}$ & 433 \\
\hline \multirow{3}{*}{ OCB } & Pearson Correlation & .000 & 1 \\
\cline { 2 - 4 } & Sig. (2-tailed) & 433 & 433 \\
\cline { 2 - 4 } & $\mathrm{N}$ & \multicolumn{2}{|c|}{} \\
\hline \multirow{2}{*}{${ }^{* *}$. Correlation is significant at the 0.01 level (2-tailed). } \\
\hline
\end{tabular}

The above table 2.1 indicates that there exist a positive relationship between employee engagement and $\mathrm{OCB}$, and the strength of the relationship is strong at .687. Further to test the extent to which dependent variable is influenced by independent variable, linear regression was used to test the hypothesis. 
Table No 2.1a Model Summary

\begin{tabular}{|l|c|c|c|c|}
\hline Model & $\mathrm{R}$ & $\mathrm{R}$ Square & $\begin{array}{c}\text { Adjusted R } \\
\text { Square }\end{array}$ & $\begin{array}{c}\text { Std. Error of the } \\
\text { Estimate }\end{array}$ \\
\hline 1 & $.687 \mathrm{a}$ & .472 & .471 & .39453 \\
\hline \multicolumn{2}{|l|}{ a. Predictors: (Constant), EE }
\end{tabular}

Table No 2.1b ANOVAa

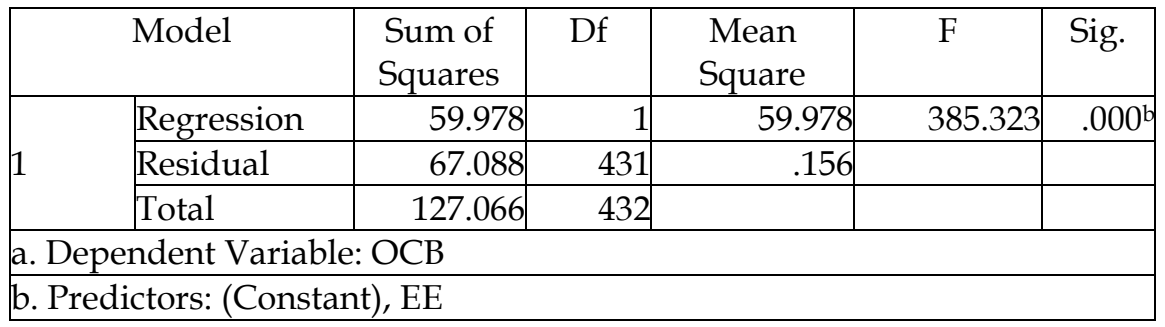

Table No 2.1c Coefficientsa

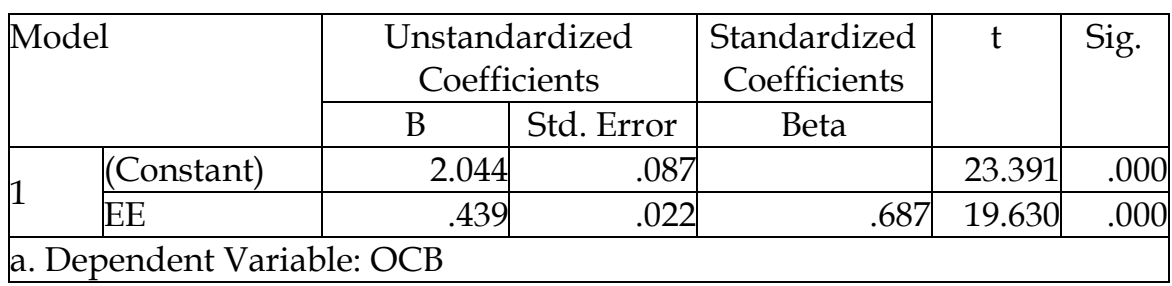

From the above table 2.1a the R-square $\left(\mathrm{R}^{2}\right)$ values is .472 and adjusted $\mathrm{R}^{2}$ is .471 , where in the difference between both these are very minimal and indicates the model is good fit and can also be inferred that the result would be $47.1 \%$ accurate even in case of the actual population.

From the table $2.1 \mathrm{~b}$ Anova table the p-value is .000 which is well below .05, therefore it can be concluded that EE and OCB has significant positive relationship. Thus alternate hypothesis is accepted and null hypothesis is rejected. Table 2.1c coefficient helps in understanding the regression equation. The following is the regression equation predicting OCB based on employee engagement (EE)

$\mathrm{Y}(\mathrm{OCB})=2.044+.439 \mathrm{X}(\mathrm{EE})$ 
Thus it can also be concluded that when EE increases by 1 unit then the OCB will be increased by $43.9 \%$.

\section{Conclusion}

All travel organizations need to ensure that employees working in their organizations are engaged in the work that they dobecause of the obvious reason that any organisation is a people centered organization withcontinuous interaction with customers. This is one sector where there is constant flow of customers and especially during the peak seasons the customer demand will be thrice or more times higher than the off seasons. In such scenario employees always need to be engaged and should be willing to take up extra work and meet their customer demands. From the study it is obvious that employee engagement positively influences OCB which means that when employees are engaged they will be willing to go that extra mile. This finding supports earlier studies (Rurkkhum, 2010; Roberson \& Strickland, 2010; Islam, Khan, Aamir, Ahmed, Ahmad \& Shaukat, 2012; Thomas, 2011;Allameh, Shahriari \& Mansoori, 2012; Mansoor et al, 2012; Andrew \& Sofian, 2012; Soane et al, 2012; Ariani, 2013). Thus organizations need to take measures that promote employee engagement. Organizations also need to understand the extent to which their employees are engaged and identify the reasons for disengagement, if any, and take steps to overcome such drawbacks. Though employee engagement positively influences $\mathrm{OCB}$, the level of influence is less than $50 \%$, thus studies in future can explore the various other factors that would positively influence OCB.

\section{References}

Allameh, S. M., Shahriari, M., \&Mansoori, H. (2012) Investigating Employee's Attitude toward Organization, Organizational Climate and Employee's Engagement as Antecedents of Organizational Citizenship Behavior Australian. Journal of Basic and Applied Sciences, 6(8), 384-393.

Andrew, O. C., \& Sofian, S. (2012). Individual Factors and Work Outcomes of Employee engagement. Procedia- Social and Behavioral Sciences, 40, 498-508. 
Ariani, D. W. (2013). The Relationship between Employee Engagement, Organizational Citizenship Behavior and Counterproductive Work Behavior. International Journal of Business Administration, 4(2), p46

Buckingham, M. and Coffman, C. (1999), First, Break All the Rules: What the World's Greatest Managers Do Differently, The Gallup Organization, Simon \& Schuster, New York, NY

Islam,T., Khan, S. U. R., Aamir,M., Ahmed,I., Ahmad, U. N. K U and Shaukat., M. Z (2012): Moderating role of HRD practices between employees' engagement and citizenship behaviour; Middle -East Journal of Scientific Research 12(5): 589-597

Kahn, W. A. (1990). Psychological conditions of personal engagement and disengagement at work. Academy of management journal, 33(4), 692-724

Macey, W. H., \& Schneider, B. (2008). The meaning of employee engagement. Industrial and Organizational Psychology, 1(1), 3-30

Mansoor, N., Aslam, H. D., Javad, T., Ashraf, F., \& Shabbir, F. (2012). Exploring Organizational Citizenship Behavior and its Critical Link to Employee Engagement for Effectual Human Resource Management in Organizations. Mediterranean Journal of Social Sciences, 3(1).

Maslach, C., \& Leiter, M. P (1997) The Truth About Burnout: How Organizations Cause Personal Stress and What To Do About It.

May, D. R., Gilson, R. L., \& Harter, L. M. (2004).The psychological conditions of meaningfulness, safety and availability and the engagement of the human spirit at work. Journal of Occupational and Organizational Psychology, 77(1), 11-37.

Organ, D. W. (1988).Organizational citizenship behaviour: The good soldier syndrome. Lexington Books/DC Heath and Com

Podsakoff, P. M., Mackenzie, S. B., Moorman, R. H., \& Fetter, R. (1990). Transformational leader behaviors and their effects on followers' trust in leader, satisfaction, and organizational citizenship behaviors. The Leadership Quarterly, 1(2), 107-142.

Rurkkhum,S (2010); The Relationship between Employee Engagement and Organizational Citizenship Behaviour in Thai Organizations 
Saks, A. M. (2006). Antecedents and consequences of employee engagement. Journal of Managerial Psychology, 21(7), 600-619.

Schaufeli, W.B and Bakker, A.B. (2001). Work and well-being: Towards a positive occupational health psychology, 229-253

Schaufeli, W.B., Taris, T. W., Le Blanc, P.M., Peeters, M., Bakker, A.B and De Jonge, J. (2001).Does work make healthy, in search of the engaged worker, 36, 422-428

Soane, E., Truss, C., Alfes, K., Shantz, A., Rees, C., \& Gatenby, M. (2012). Development and application of a new measure of employee engagement: the ISA Engagement Scale. Human Resource Development International, 15(5), 529-547.

Thayer, S. E. (2008). Psychological climate and its relationship to employee engagement and organizational citizenship behaviors. ProQuest.

Thomas, E. A. (2011). Personality characteristics and behavioral outcomes associated with engagement in work-related roles. Alliant International University, Los Angeles. 